\title{
The political economy of sharing
}

\author{
Evgenii Bogomolov $^{1}$, Olga Orusova ${ }^{1, *}$, and Maria Ekaterinovskaya $^{1}$ \\ ${ }^{1}$ Financial University under the Government of the Russian Federation, Economics Department, 49 \\ Leningradsky Prospekt, 125993 Moscow, Russian Federation
}

\begin{abstract}
The widespread adoption of a new model of economy - the economy of shared consumption (public services for short-term rental of bicycles, cars, apartments, houses, other goods and services) - has raised many questions for the economic theory. What is a shared economy? What are the reasons for its appearance in different countries? How does it change property relations? What is its future? The answers to these questions are considered using the publications of Russian and foreign scientists. The authors conclude that sharing economy is just a new variant of capital system adaptation.
\end{abstract}

\section{Introduction}

The economy of "collaborative" consumption or "sharing" economy appeared in a strict connection with universal digitalization, the creation of network interaction through Internet services. An amazing symbiosis of private property and public consumption, or a model of joint consumption, has appeared within the capitalist system. It is based on the joint or collaborative consumption and use of goods and services on the basis of barter or lease relations, as opposed to private property and private sole ownership and use. The possibility of implementing such consumption arose due to the rapid development of digital technologies, the Internet, mobile communications, the creation of Internet platforms and special applications.

The purpose of this study is to formulate problems that require a comprehensive analysis in connection with the development of public relations regarding the goods sharing.

The research method is a systematic analysis of the ongoing processes in the field of collaborative consumption and their interpretation in various studies.

The terms "sharing" economy and "collaborative" or joint consumption, according to some economists, have the same meaning, and the authors of this study adhere to this point of view and use the two terms with the same meaning [1]. The principle of the sharing economy is that without owning a good, people get the opportunity to use it. Just as temporarily free money in a market economy is constantly in circulation, so the free excess resources of some people can be used by other people who need them. Resources here are a variety of benefits: equipment, tools, machines, equipment, cars, housing, skills and abilities,

*Corresponding author: oorusova@,fa.ru 
information, free time. Many special services connect those who own such goods with those who need them.

\section{Definition and Bibliography}

In the published foreign and Russian scientific works, various definitions of the concept "sharing economy" are given. There is no consensus on the time of this term's appearance. The study of L. Belova indicates that the term "collaborative consumption", which appeared back in 1978, became a harbinger of the sharing economy [2]. The researchers M. Felson and J. Spaeth explained the future popularity of collective use of goods and services due to the widespread use of barter and rent instead of ownership [3]. The study of E. Platonova notes that the first appearance of the sharing economy is associated with the publication in 2002 by the Swedish researcher A. Styhre, in which the increasing role of knowledge-intensive companies in the economy was analysed [4]. A. Styhre wrote that joint activity in knowledgeintensive organizations and the subsequent use of its high-tech products are based on exchange, and not on exploitation and appropriation [5]. Foreign researchers of the economy of collaborative consumption were B. Matofska [6], R. Botsman [7], E. Luyckx and D. Masset [8], etc.

The term came into a wide use about 10 years ago, thanks to the book by the American economist Lawrence Lessig "Remix". Analysing the differences between the commercial and sharing economy, he pointed out that, like any economy, the sharing economy is built on exchange, but exchange within its framework cannot be completely defined in terms of money. Unlike commercial economies, in which prices are the main source of information about the distribution of resources, in sharing economies this role is played by non-price factors (social relations) [9].

The "monetized" concept of collaborative consumption, in which monetary payment for sharing services is recognized as mandatory, was formulated only in 2010. Describing the new socio-economic model, R. Botsman and R. Rogers emphasized: the main idea is that it is often more profitable and convenient for the consumer to pay for temporary access to a product than to own it, and that such a model should revolutionize the consumption of goods and services [10].

According to the American economist R. Thaler, the sharing economy is the economy model of "collaborative consumption" in which the masses get or give for rent the assets (without rights of ownership on them) with the aim of obtaining mutual benefits [11].

M. Pedroni understands the sharing economy as socio-economic relations provided by sharing platforms and associated with short-term access to private resources [12].

According to the study by the Russian scientists M. Shatkin and L. Yakovleva, the sharing economy is one of the interpretations of the concept of private property, in which the use of it by another person imposes certain restrictions on its owner [13].

The work by E. Avdokushina and E. Kuznetsova "The economy of joint consumption: the essence and some development trends" substantiates the thesis that the sharing economy consists of both the economy of joint consumption and the economy of joint use. "If joint consumption is basically a simple cooperation between individuals for the exchange, donation, use of goods and services, then joint use is the exchange of goods and services between legal entities, as a result of which there is an alienation not of property, but only of the results of owning it, and, as a goal, making a profit" [14].

T. Chumakov believes that the sharing economy simplifies, reduces the cost and accelerates the process of obtaining services, leading to savings on transaction costs, which allows solving problems associated with inefficient use of resources, resource savings, environmental problems, etc. [15]. 
According to $\mathrm{Zh}$. Tropina, thanks to joint consumption, the sharing economy simplifies the model of interaction between producers and consumers, because the distribution of goods and services occurs without intermediaries [16].

\section{Reasons for Sharing}

So, the sharing economy is the system of economic relations set to meet needs without transferring ownership of the goods.

Does this interaction represent a new type of economic relations, or are they the former relations exposed in a new technical form?

The emergence of collaborative consumption is associated with the financial and mortgage crisis of 2008, another crisis of the capitalist mode of production. This crisis was associated with another accelerated growth of fictitious capital in relation to the weak growth of the real capital. At first, fictitious capital grew on the expectation of income from the Internet technologies, and after the so-called "dot-com crash", on the expectation of income from housing construction. A sharp decline in income led to the need for more rational consumption; at the same time, the owners of capital began to look for the application of the investments results in developing network interaction technologies, to the former relations of sharing (transfer of the right to use) material goods.

The entire economy of mutual use is based on information platforms that can significantly simplify all the processes of rental relations. The transaction costs of the lease are reduced, which leads to the efficiency of temporary use compared to long-term use as a result of the full transfer of ownership (purchase).

Another reason for the sharing economy development is the tendency to deepen inequality. Income inequality, which decreased due to the social policies of the developed countries of the world in the second half of the 20th century, began to grow again in the $21 \mathrm{st}$ century. The growth of inequality leads to the fact that in order to ensure profitability and sales of products, the owners of capital are forced to purchase goods themselves, with subsequent leasing them to those who, due to relatively low incomes, cannot afford to purchase goods in ownership. That is, the problem of excess production in the interpretation of Marxism was solved through a certain approximation of the private appropriation of the results of production to public appropriation through the temporary transfer of the right of use [17].

The collapse of communist regimes and the surge in unemployment after the 2008 crisis (for example, in the United States, the share of unemployed increased twice, and the share of long-term unemployed is even greater), N. Srnichek considers the basis for the emergence of a new type of an employee - with the absence of long-term labour relations, and, accordingly, a stable income [18]. In the United States, the share of such workers increased from $10.1 \%$ in 2005 to $15.8 \%$ in 2015 . The inability to plan long-term consumption for such workers is precisely the incentive to use short-term rental of goods to meet their needs. At the same time, such employees are also the main source of labour resources for the sharing economy.

The economy of mutual consumption is by no means a new model for Russia. In the recent Soviet past, low personal incomes were compensated by joint consumption in the form of rental of household appliances and tourist equipment, cooperative trade in rural areas, machine and tractor stations (sharing of agricultural equipment).

Sharing is impossible without mass participation. The more participants there are, the more efficiently the product is used (a positive scale effect by reducing the average conditionally fixed costs of owning it). It is no coincidence that the development of sharing is actively going on in large cities, with a large number of potential participants. For example, in 2018, more than ten car-sharing companies worked in Moscow, the largest in terms of the number of cars were: Delimobil (it accounted for $23 \%$ of the total fleet), Yandex.Drive 
(22\%), BelkaCar (20\%). At the same time, a net loss for this year occurred for all major players: Yandex.Drive - 550 million roubles, BelkaCar - 386 million roubles, Delimobil 258.7 million roubles [19]. Hence, there was a justified tendency of all sharing platforms to expand and monopolize. So, in 2020, there are only 6 players left in the Moscow car-sharing market [20].

The head of the Bank of Russia, E. Nabiullina, expressed concern about the monopolization of the market by large ecosystems of banks [21]. Sberbank is taking the most active actions in this direction, building the Sber system, which includes a number of sharing platforms: Citi-mobil (taxi services), Sberbank services (services), YouDrive (car-sharing). The essence of such ecosystems is to concentrate and retain a large number of consumers.

The services provided by subscription are also aimed at retaining customers. Using for a subscription fee is not new, however, now it covers more and more new areas. The reason is the same drop in income, a decrease in the level of savings, which makes it difficult to buy long-term expensive goods (car, housing, etc.). For example, during the hot summer in Russia in 2021, the MTS ecosystem offered services for installing and using air conditioners for an annual subscription fee.

Another reason for developing the sharing economy is the weakening of institutional trust. Thus, in the work by E. N. Nikishina, it was determined that with the development and complexity of human society, trust between individuals or groups weakened in parallel with the growth of institutional trust (courts, police, government, etc.) [22-25]. The capabilities of sharing platforms can regain trust that is not based on formal institutions: "... sharing companies based on digital platforms can be effective not only because they reduce the cost of receiving services (including by reducing the number of links between the supplier and the buyer), but also because they carry a specific mechanism for ensuring the reliability of obligations, reducing transaction costs and allowing strangers to carry out mutually beneficial interaction."

In the modern world, under the influence of the COVID-19 pandemics, the trend towards saving is increasing in all countries, both poor and rich: saving money, saving expenses, saving resources, saving time and effort. That is why the sphere of joint commodity consumption is increasing, which allows optimizing expenses in various ways. This is another reason for the wide spread of the sharing economy in the future.

\section{Conclusions}

The sharing economy is not a fundamentally new model of the economy and is a form of capital adaptation to the non-vanishing contradiction between the social nature of production and the private appropriation of its results. Income inequality increase, reducing the rate of return and striving for value increase from more efficient consumption, the development of digital technologies and institutional trust weakening are the driving forces of the sharing economy development.

\section{References}

1. T. Chestina, Sharing economy (Sharing economy) vs Hyperconsumption, Electronic journal. Natur Product. Category: Responsible choice, http://npmag.ru/dela/otvetstvennyvybor/sharing-economy-sheringekonomika-vsgiperpotreblenie - 2020-HTML.html

2. L.G. Belova, World Economy and International Relations, 5, 87 (2021)

3. M. Felson, J.L. Spaeth, American Behavioral Scientist, 21 (March-April), 614 (1978) 
4. E.D. Platonova, Bulletin of Eurasian Science, 1, https://esj.today/PDF/14ECVN119.pdf (2019)

5. A. Styhre, Knowledge and Process Management, 9(4), 228 (2002)

6. B. Matofska, What is the sharing economy? The people who share, URL: www.thepeoplewhoshare.com/blog/what-is-the-sharing-economy/ (2016)

7. R. Botsman, Fast Company, 27 (2015)

8. D. Masset, E. Luyck, Analyse Etopia, 30, 7 (2014)

9. L.L. Lessig, Remix: Making Art and Commerce Thrive in the Hybrid Economy. London, Bloomsbury Academic, 300 (2008)

10. R. Botsman, R. Rogers, What's Mine Is Yours: the Rise of Collaborative Consumption. New York, Harper Collins, 644 (2010)

11. R. Thaler, The new behavioral economy. Why people violate the rules of the traditional economy and how to make money on it, Moscow, Eksmo, 320 (2017)

12. M. Pedroni, Sharing Economy as an Anti-concept. First Monday, 24, 2, https://journals.uic.edu/ojs/index.php/fm/article/view/9113/7732 -2018-HTML.html

13. M.A. Shatkin, L.S. Yakovlev, Sociological research, 1, 31 (2020)

14. E.F. Avdokushin, E.G. Kuznetsova, Economic Journal, 2, 6 (2019).

15. T.V. Chumakov, Scientific research of the Faculty of Economics, 8, 3, 5 (2016)

16. Zh.

$\mathrm{N}$.

Tropina,

IEAU,

http://www.ieay.ru/assets/files/new_archive/nauka_v_ieay/files/vestnikieay/24/Tropina .pdf -2019 - HTML.html

17. F. Engels, The development of socialism from utopia to science. K. Marx, F. Engels, $\begin{array}{lllll}\text { collected } \quad \text { works, } & \text { ed. } & \text { URL: }\end{array}$ https://www.esperanto.mv.ru/Marksismo/Razsoc/razsoc-3.html\#p43 -2021HTML.html.

18. N. Srnichek, Capitalism of platforms. Moscow, HSE Publishing House, 33 (2019)

19. Yandex.Drive became the third carsharing by revenue after the disclosure of data, $\mathrm{RBC}$, https://www.rbc.ru/technology_and_media/06/08/2019/5d4971ba9a794722d38e4f24 2019 - HTML.html

20. The sharing market in Russia for the first time exceeded 1 trillion roubles, RBC. Trends. URL: $\quad$ https://trends.rbc.ru/trends/sharing/602e3a369a79477994233cb3 -2021HTML.html

21. Nabiullina announced the risk of "powerful" ecosystems against the background of the sale of Sberbank. RBC: Finance. https://www.rbc.ru/finances/13/02/2020/5e4532f99a7947425951b1ab -2020HTML.html

22. E.N. Nikishina, Bulletin of the Moscow University. Series 6: Economics, 4, 71 (2020)

23. V. Dementyev, N. Dalevska, A. Kwilinski, Virtual Economics, 4(1), 54-76 (2021)

24. A. Kwilinski, H. Dzwigol, V. Dementyev, International Journal of Entrepreneurship, 24(1 Special Issue), 1-5 (2020)

25. V.V. Dementyev, A. Kwilinski, Journal of Institutional Studies, 12(1), 100-116 (2020) 